\title{
SOME ENDOCRINE CHANGES IN LIVER DISEASE
}

\author{
G. A. Martini, M.D. \\ Assoc. Professor of Medicine, University of Hamburg (Germany)
}

Amongst the numerous metabolic functions of the liver are those concerned with the catabolism or inactivation of hormones. One would therefore expect to find liver disease frequently accompanied by endocrine disturbances; and attempts to correlate certain liver disease with disturbances in endocrine function are not new. In addition, there are certain features of liver disease such as the 'characteristic' skin changes which are attributed to altered hormone metabolism.

The close relationship between liver disease and the gonads appears to be obvious. In the male there is gynæcomastia and an alteration in the secondary hair distribution with loss of axillary and chest hair and a female distribution of pubic hair. Loss of libido, impotence and testicular atrophy complete the characteristic picture of hormonal disturbances in the human male with chronic liver disease. Oligospermia is common (Voegt and Weller, 1959). Prostatic hypertrophy in men with chronic liver disease is rare (Stumpf and Wilens, 1953). The incidence of these endocrine disturbances varies remarkably as between different countries. Gynæcomastia and testicular atrophy, a combination also known as the Silvestrini-Corda syndrome after the authors who first described it (Corda, 1925; Silvestrini, I926), was found by Lloyd and Williams (1948) to occur in $42 \%$ of 55 men with cirrhosis of the liver. The same workers reported $75 \%$ incidence of testicular atrophy in their patients. However, the incidence of gynæcomastia in our own cases and in others, as for instance in England, is distinctly low. The same applies to other signs of chronic liver disease such as parotid swelling and Dupuytren's contracture (Davidson, Sherlock, Summerskill, Turner and Wolfe, 1960). It is quite possible that alcoholism alone, or rather the accompanying malnutrition, like that in prisoners of war during the period of nutritional re-feeding (Klatskin, Salter and Humm, I947; Kark, Morey and Paynter, I95I), plays a decisive part in the development of these signs. 'Alcoholic' cirrhosis predominates in the American cases, but is not nearly so common in England or in Germany.

Moreover it is difficult to determine whether the altered distribution of secondary hair is constitutionally conditioned or whether it is the result of liver disease. Since Chvostek described the 'habitus' known by his name it has not been possible to determine whether or not men with this type of constitution are more susceptible to the development of cirrhosis. It is therefore very important to question patients about their hair distribution in the 'pre-cirrhotic' phase. Many patients can provide evidence and often photographs to prove that they never had a heavy growth of pectoral, axillary or pubic hair before developing cirrhosis.

Women with chronic liver disease usually have amenorrhœa or dysmenorrhœa and may have cystic mastitis or acne. Sterility is the rule and conception is very rare. In certain age groups, about puberty (Bearn, Kunkel and Slater, r956; Waldenström, I952) and after the menopause (Alsted, I947; Cattan, Vesin and Bodin, I957; Martini and Dölle, I960), women are prone to develop a peculiar form of hepatitis of unknown ætiology with a chronic course and with 'postnecrotic' cirrhosis. Altogether the sex ratio of postnecrotic cirrhosis in women to men is $3: \mathrm{I}$, in contrast with Laennecs's cirrhosis, which is preponderant in men. Women who develop virus hepatitis during the menopause are especially susceptible to the development of postnecrotic cirrhosis.

Both men and women with chronic liver disease develop certain vascular changes in the skin, such as arterial spiders, 'white spots' (Martini and Staubesand, 1953; Martini, 1955) and palmar erythema. These skin changes occur with almost equal frequency in pregnant women and disappear again soon after parturition. These observations led Bean, (1945) to regard the vascular changes as a manifestation of 'hyperœstrogenism'. An increase in œstrogens is a normal feature of pregnancy. In chronic liver disease the liver is said to be incapable of inactivating œstrogens; hence the œstrogen level in the blood rises. This interpretation is disarmingly simple. It was indeed possible to induce the development of arterial spiders and palmar erythema in one third of 30 
patients with cirrhosis by the administration of œestrogenic substances, but two thirds of the patients showed no such response (Bean, 1958). Nor have such phenomena been observed in patients with carcinoma of the prostate who have received very large doses of œstrogens. In any case a purely hormonal factor would not explain the localisation of the spider nævi and their distribution. They are practically confined to the so-called exposed parts of the skin (face, neck and arms). This localization suggests that beside the hormonal or 'internal' factor in the production of arterial spiders, an 'external' factor may be operating: the structure and function of the affected portion of the skin and of its smallest vessels and their altered reaction to the action of sunshine, wind and light (Martini, 1955).

The most important question, however, is whether there is actually an œstrogenic excess in patients with chronic liver disease and if so, whether there is any correlation between the œstrogen levels and the clinical signs such as gynæcomastia, altered hair distribution and skin changes.

\section{The Metabolism of Cstrogens}

Our knowledge about the nature and quantity of circulating cestrogens in the plasma of patients with liver disease is scanty, and therefore the evidence in favour of the before mentioned 'hyperœstrogenism' in liver disease remains circumstantial (Diczfalusy, 1962). In pregnancy the ratio unconjugated (free) to conjugated 17- $\beta$-œstradiol was higher than similar ratios for œstrone and œstriol. If this could be confirmed in patients with liver disease it could well be that this shift towards free estradiol accounts for the 'hyperœstrogenism' (Diczfalusy, 1962).

Since Zondek's work (1934) it has been known that the healthy liver plays an important part in the inactivation of œstrogenic hormones. In this process conjugation of the hormones with glucuronic acid or sulphuric acid is particularly important. However, it is still not decided whether conjugation and inactivation are one and the same thing or not (Cameron, $1957 \mathrm{a} \& \mathrm{~b}$ ). It has been found that under certain conditions the glucuronic acid ester of the hormones is apparently as active as the free hormones. Some conjugates, when administered, are easily hydrolyzed in the body. In contrast to other steroid hormones which are inactivated by enzymatic reduction before conjugation, œstrogens are conjugated in the active form.

It seems doubtful whether the estimation of free and conjugated œestrogens can in any way yield more information about disturbed liver function. Even if this particular liver function of conjugating œstrogens were disturbed there would still be the intestine to compensate for it. According t⿳⺈ Sandberg and Slaunwhite (1957), there exists an entero-hepatic circulation of œstrogens not onlø in animals but also in man. When radioactive. œstrogens were given, $50 \%$ of the radioactivit $\overrightarrow{\mathrm{F}_{5}}$ .was recovered in the bile, but only $7 \%$ excreted in the fæces. Up to $80 \%$ was excreted in the urine $\frac{C}{O}$ It is not yet decided whether œstrogens are absorbed as free œstrogens after hydrolyzation ir the intestine or in conjugated form. It was shown recently that in man the intestine is able tơ conjugate free cstrogens which were brought int $\overrightarrow{0}$ the intestinal lumen at operation (Diczfalusy Frankson and Martinsen, I96r). A retardation in this bilio-entero-hepatic cycle was postulate 6 by Rupp, Cantarow, Rakoff and Paschkis (195 I and Dohan, Richardson, Bluemle and Györgye. (1952), to account for the disturbed œstrogen metabolism in patients with cirrhosis.

A further difficulty arises from the indecision about which of the various known œstrogenie hormones is to be regarded as the primary hormone? Oestradiol, œstrone and œstriol have all been nominated. But these three represent only $20 \%$ of all œstrogens. Brown and Marrian (1957) suggested the following metabolic pathways for these œstrogens:

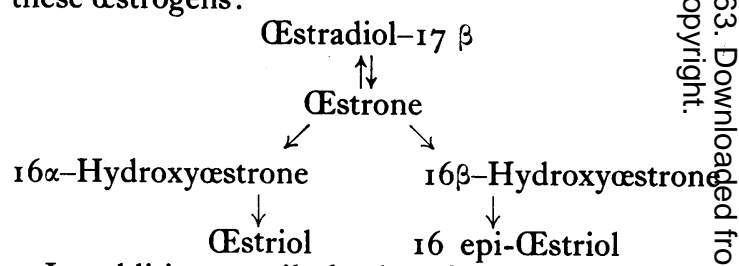

In addition, until the last few years the only method available for estimating œstrogens was? the biological method of the Allen-Doisy test this was the method used in most of the reported studies of œstrogen excretion in liver disease? Since then new biochemical methods have beens developed, and it is expected that they wills. provide more accurate quantitative information. Comparison of the two methods is rendered even more difficult by the fact that they estimate different œstrogenic fractions. The Allen-Doisy? test estimates œstradiol rather than œstrone or œstriol, whereas Brown's biochemical methodo estimates all three hormones, (1955). Although much work has been done in the past there is no clear answer yet to the question whether the $\mathrm{e}^{\mathrm{\omega}}$ excretion pattern of cstrogens differs quantitatively and qualitatively in patients with livero disease from that in normals.

The results obtained with the biochemical $\stackrel{\text { क }}{+}$ method are in direct contrast with those obtained ${ }^{-}$ by means of the biological assay (Bennett, $\stackrel{\overrightarrow{\mathbb{D}}}{\mathrm{P}}$ Baggenstoss and Butt 1950; Dohan and others, $\frac{\stackrel{\oplus}{\mathbb{Q}}}{\circ}$ 
1952; Glass, Edmonson and Soll, r944; Rupp and others, I95I), which had shown an increase in total œstrogen excretion in nearly half of the patients with cirrhosis, the hormones appearing in the urine mainly as free cestrogens. This was also shown by Müller (1958) using a fluorimetric method. Cameron (1957) was not able to confirm these results using Brown's method. He found, as others had done before him, (Pincus, Rakoff, Cohn and Tumen, I95I) that there was no increase in free œstrogen excretion in his group of 12 patients with cirrhosis, except in 2 . His most remarkable finding in half of his patients was an increase in the proportion of œstriol excreted with a corresponding reduction in the amounts of œstrone and œstradiol. This was the result in measuring the excretion of endogenous œstrogens. When larger amounts of œstradiol were adminisstered in patients with severe liver disease a 'shift' towards increased œstradiol excretion took place (Lyngbye and Mogensen, I96r).

The discrepancy between the results of the biological and the biochemical assays can be explained by postulating that certain of the newly identified œstrogenic hormones, such as epiœstrol or $16 \alpha$-hydroxyœstrone, are responsible for the endocrine stigmata in patients with cirrhosis: the œstrogenic activity of these substances would be apparent in the biological assay, but not in the biochemical method employed.

In fact, I $6 \alpha$-hydroxyostrone seems to be just as active as estriol (Loraine, 1958), and has been demonstrated in considerable amounts in the urine of pregnant women (Brown and Marrian, 1957). An inhibition of the conversion of cestradiol into œstriol was demonstrated by Lyngbye and Mogensen (196r). If such an inhibition occurred in the conversion of $16 \alpha$-hydroxyœstrone into œstriol the former substance could accumulate without being estimated in the urine by the biochemical method.

It is important, however, not to seek facile explanations until reliable quantitative results about œstrogen excretion have been obtained. It may then perhaps be possible to establish that a definite correlation exists between the particular endocrine features in liver disease and both the quantity and the quality of œstrogens excreted. The morphological changes in the endocrine organs of patients with cirrhosis nevertheless suggest a strong œstrogenic effect (Bennett and others, 1950; Barr and Sommers, I957): approximately half of 30 female patients had adenofibrosis of the breast or cystic mastitis and endometrial hyperplasia. Two thirds of 70 male patients examined showed the 'characteristic' changes in the prostate and testis. Other remarkable findings in these male patients were a marked increase in the basophil cells of the pituitary and adrenal atrophy.

Again it will be necessary to consider the variety in 'normal' levels, depending on race, nutrition, age etc. For instance normal Bantu males are reported to have a much higher œstrogen excretion than normal white males in South Africa. The cestradiol fraction was particularly increased in these Bantus. In Bantus with chronic liver disease the œstradiol fraction further increased.

In white men with liver disease it was the œstriol fraction which increased. One can speculate whether malnutrition causes an increase of 'normal' œstrogen levels and/or changes its pattern and moreover, if this increase in turn causes liver disease and cancer with breast changes which are so frequent in Bantus (Bloomberg and others, 1958; quoted in Diczfalusy and Lauritzen, 196r.

\section{The Metabolism of Androgen}

The original findings of Fraser, Forbes, Albright, Sulkowitch and Reifenstein (I94I), that the excretion of 17 -ketosteroids is diminished in the urine of patients with chronic liver disease have repeatedly been confirmed and are considered firmly established (Peterson, 1960). Birke and others found the urinary output of 17 -ketosteroids in cirrhotics both male and female as low as in adrenal cortical insufficiency (Birke 1962). Even after testosterone administration the urinary output of 17 -ketosteroids is much decreased in patients with liver disease. Whereas some authors (Williams, Cantarow, Paschkis and Havens, $195 \mathrm{I}$; Birke, 1962) found no decreased ability to convert testosterone to 17-ketosteroids, some others thought it to be disturbed (West, Tyler, Brown and Samuels, 195I). Both the conjugation with glucuronic acid and sulphuric acid are disturbed (Birke, Diczfalusy and Plantin, I959), but no free I7-ketosteroids were excreted (Bongiovanni and Eisenmenger, 195I). Apparently both the 17-ketosteroids originating in the adrenal cortex and in the testis are diminished (Cameron, 1957). However, this diminution is probably not alone due to faulty conversion of testosterone to I7ketosteroid, but to reduced androgen production as well. The resultant imbalance between androgens and œstrogens could also account for the 'hyperœstrogenism' even in those males who have a normal œstrogen output in the urine. For there is an undoubted antagonism between ostrogens and the other steroid hormones (Szego and Roberts, 1953). The diminution in androgen production still requires explanation. An excess of œstrogens might depress androgen production by inhibiting the production and release of gonadotropin from the pituitary gland. The 
urinary gonadotropin excretion has been found to be greatly reduced in some cases (Voegt and Weller, 1958). Or, there could be a primary reduction in androgen production owing to malnutrition with protein deficiency which frequently accompanies alcoholic cirrhosis. Reduced pituitary function in malnutrition was reported by Fletcher and Brown (1959). Another possibility is the direct damaging effect of alcohol on the endocrine system; for the 'endocrine stigmata' are undoubtedly more common in alcoholic cirrhosis than in posthepatitic cirrhosis. But this is speculation.

\section{Adrenal Hormones}

The great deal of interest aroused in recent years by the adrenal hormones has also directed attention to the relationship between adrenal cortical hormones and the liver. There are certain clinical observations which suggest disturbances in adrenal hormone metabolism but the exact nature of these disturbances has not yet been defined. Bearn and coworkers (1956) have described signs of 'hypercorticism' especially in the peculiar form of chronic hepatitis which occurs in girls and young women. The signs include acne, moonface, striæ, and more rarely hirsutism. These girls often have amenorrhœa and react to œstrogen administration by rise in the bilirubin level. Waldenström (1952) has reported similar findings. The incidence of each of the signs ascribed to adrenal cortical hyperfunction is so variable that there is a good deal of justified doubt about the existence of such a syndrome. (Willcox and Isselbacher, 1961). This group of patients does more commonly share other signs such as polyarthritis and hypergammaglobulinæmia, rarely the LE-cell; and it has therefore been suggested that an autoimmune pathological process may be involved (Mackay, 196r). Incidentally, these patients respond particularly well to cortisone treatment. Further details about the treatment of liver disease with corticosteroids will not be discussed here and the reader is referred to the paper by Goldgraber and Kirsner (1959).

Recent observations have shown the importance of the liver in the elimination of exogenously administered hydrocortisone. Only about $1 \%$ of the free form of this hormone appears in the urine. About $3 \%$ is excreted as unconjugated metabolites, 80 to $90 \%$ appears as conjugated, water-soluble metabolites (Schedl, I962). In mice about $70 \%$ of labelled hydrocortisone was found in the liver within five minutes of administration. Plager, Tyler, Hecht and Samuels (1954) have reported similar findings in man. They detected much less radioactivity in the hepatic venous blood than in the arterial blood after intravenotit administration of radioactive hydrocortisone.

In patients with chronic liver disease the plasm levels of free corticosteroids and its rise afte ACTH administration were the same as in normat subjects (Englert, Brown, Wallach and Simo 1957; Birke and others, 1959). However, hydrê cortisone administered to patients with liver disease disappeared much more slowly from the bloo, stream and appeared in the urine in much lowert concentration than in normal subjects. Suf prisingly, cortisone, corticosterone and tetrahydrơ cortisone were found to disappear from the bloo $\bar{\phi}$ stream with equal rapidity in patients with livert disease and in normal subjects (Englert ans others, 1957; Peterson, 1960). These findings are best explained by the existence of a specific TPNH dependent enzyme, the $\triangle-4$-hydrogenase, whic $\vec{b}_{0}$ reduces cortisol to dihydrocortisol. Dihydroe cortisol is then further reduced to tetrahydrơf cortisol. These reduced forms are conjugated ino the liver with glucuronic acid or sulphuric aci\$ and then excreted in the urine. Apparently it is only the enzymatic reduction which is disturbed in liver disease and not the conjugation with glucuronic acid. When the 'right' combination are presented as for instance tetrahydrocortisoto conjugation proceeds normally (Brown, I9 9ु The amount of urinary unconjugated steroids ip patients with liver disease seems to be slight raised above normal and consists mainly of $6-\beta<$ hydrocortisol (Katz, Lipman, Frantz and Jaile I962).

Thus it appears that the rate of cortisol meta $\stackrel{\mathcal{Q}}{2}$ bolism is decreased in liver disease. The bod $\vec{\Phi}$ pool of cortisol is normal or slightly increased, whereas the turnover rate of the pool is about half normal (Peterson, 1960). This means that in. patients with liver disease the physiologic action of cortisol is prolonged. This in turn will inhibit. corticotropin secretion and thus consequently leag to the depression of cortisol synthesis and secretion. These patients-although seemingly being 'eucorticoid'-actually have an adrenal cortical insufficiency as regards the quantity of cortiso synthesized (Schedl, I962). Since the diseased liver has partly lost its capacity to inactivate cortisol the plasma level remains within the normat range. It has frequently been noted that the adrenal glands of patients with cirrhosis are small in size with narrow cortices and a decreaseg. lipoid content (Barr and Sommers, 1957). WE realise then that the liver together with the adrenal and the pituitary plays an important paro in the corticosteroid homœostasis of the organism (Birke, 1962).

These observations are particularly interestin in comparison with rather different recent findings 
in relation to the other equally important adrenal hormone, aldosterone (Koczorek and Wolff, 1959). Aldosterone plays a very special role in the pathogenesis of ascites. The patients with cirrhosis lose the ability to excrete sodium and water at some particular point of time. Sodium and water then undergo excessive reabsorption by the renal tubules. Sodium reabsorption is largely influenced by aldosterone which is excreted in the urine in greater than normal amounts in cirrhotic patients with ascites (Luetscher and Johnson, I954; Wolff, Koczorek and Buchborn, 1958). However, as other patients with odema but with normal liver function also excrete excessive quantities of aldosterone in the urine, it seems that aldosterone is probably not solely and primarily responsible for the development of ascites.

Normally $60 \%$ of the endogenous production of aldosterone is excreted as a glucuronic acid conjugate of tetrahydroaldosterone which is biologically inactive; about $20 \%$ is excreted as the socalled 3-oxo-conjugate which can be converted to aldosterone by acidification of the urine at pH I (the so-called $\mathrm{pH}$ I extractable conjugate). Only $0.2 \%$ of the total is excreted as free aldosterone. About $20 \%$ of the excreted metabolites are not yet identified (Koczorek, i962). Both of the major metabolites of aldosterone are formed in the liver. In patients with chronic liver disease the altered metabolism of aldosterone is characterized by an increased aldosterone secretion rate and a decreased rate of plasma clearance, the plasma half-life time of labelled steroid being 68 minutes against 35 minutes in normals it is further characterized by an increase in the proportion of aldosterone which is metabolized to the 3-oxoconjugate and a decrease in the proportion which is converted to tetrahydroaldosterone (Coppage, Island, Cooner and Liddle, I962). The data on aldosterone secretion, however, are somewhat conflicting. Not in all investigations was the secretion rate found to be increased, but sometimes to be decreased. This perhaps could be explained by the different degree of impaired liver function. Thus in patients with cirrhosis and ascites the aldosterone levels in urine are usually markedly increased whereas in patients without ascites normal or only slightly raised levels are found.

In the belief that the adrenals play a dominant role in the development and maintenance of ascites surgeons have undertaken bilateral adrenalectomy on individual patients who had failed to respond to medical efforts at inducing diuresis (Marson, 1954; Giuseffi, Werk, Larson, Schiff and Ellioth, 1957). After operation there was a sodium diuresis but no definite water diuresis and the reaci:umulation of ascites was prevented only by use of diuretics and a low sodium diet- - measures which had proved ineffective before adrenalectomy.

This operation has been rendered obsolete by the use of aldosterone antagonists. This will not be discussed here but the reader is referred to a recent monograph (Bartter, 1960).

As mentioned before, adrenal factors are not primarily responsible for the disturbances in water and electrolyte balance in patients with chronic liver disease. Preedy and Aitken (1956 a \& b) have shown that the administration of œstriol is followed by well marked sodium and water retention in cirrhotic patients with ascites. Cirrhotic patients without ascites behaved like normal subjects and showed no sodium or water retention when given œstriol. They concluded that the salt-retaining action of cestriol depended mainly on the blood-flow through the liver and only secondarily on disturbances in liver cell function. Recently Layne, Meyer, Vaishwanar and Pincus (1962) showed that aldosterone secretion could be increased by œstrogen administration. If the same occurred in patients with liver disease, this could explain the salt-retaining effect of œstrogen.

On the whole, the interdependence of hormones and their metabolites will certainly influence the regulation of steroid metabolism and makes it even more difficult to judge the specific action of one hormone.

In normals; for instance, the œstrogens increase the binding of cortisol to the protein 'transcortin' (an $\alpha$-globulin) and, if this is saturated, to plasma albumin. This means that less free or active, and more protein-bound or inactive cortisol is circulating (Mills, Schedl, Chen and Bartter, I960). Estrogens equally prolong the plasma half-life of cortisol but not of the dihydro or tetrahydro compounds of this steroid; besides they decrease the synthesis rate of cortisol (Peterson, Nokes, Chen and Black, I960). Thus it appears that this 'œstrogen-effect' in persons with normal livers is very similar to the disturbed cortisol metabolism in patients with liver disease. Could it be that the supposed 'hyperœstrogenism' in patients with cirrhosis accounts for this? Eymer, Schwarz and Weinges, (1961) reported that the 'œstrogeneffect' is missing in patients with chronic liver disease. Cortisol did not increase after administration of œstriol. Bücher suggested that this might be due to the lack of proteins in cirrhosis (discussion of Eymer's paper).

Birke (1962) recently has stressed the fact that different hormones can act differently on the catabolism of steroids by enhancing (œstrogens, hyperthyroidism) or diminishing (androgens, hypothyroidism) the ability of the normal liver to act on the $\triangle^{4}-3$-ketosteroids, or, vice versa, on 
the side chain. The implication of these observations on the steroid catabolism in disturbed liver function must be awaited, but here certainly is a fascinating field for future research.

\section{The Antidiuretic Hormone}

Finally, brief mention must be made of the antidiuretic hormone (ADH) of the pituitary; its significance in the development and maintenance of ascites has not been clarified. Wolff and others,
(1958) found no difference between the antidiuretic hormone plasma level in healthy subjeats and in patients with liver disease. Lee a Bisset (1958) on the other hand were able to detect higher levels of antidiuretic hormoñe activity in blood from the internal jugular ve्द्धुn than in blood from the median cubital vein atd they found a distinct elevation of antidiurefic activity in blood from the internal jugular vein in 5 patients with cirrhosis and ascites. The sig $\overline{\mathrm{Di}}-$ ficance of these findings awaits interpretation.

\section{REFERENCES}

Alsted, G. (1947): Studies on Malignant Hepatitis, Amer. F. med. Sci., 213, 257.

BARr, R. W., and Sommers, S. C. (1957): Endocrine Abnormalities Accompanying Hepatic Cirrhosis and Hepator F. clin. Endocr., I7, I017.

BARTTER, F. C., Editor (1960): 'The Clinical Use of Aldosterone Antagonists'. Springfield, Illinois: Charles C Thonfess. BeAN, W. B. (1945): The Cutaneous Arterial Spider: a Survey, Medicine, 24, 243.

- (1958): 'Vascular Spiders'. Springfield, Illinois: Charles C. Thomas.

Bearn, A. G., Kunkel, H. G., and Slater, R. J. (1956): The Problem of Chronic Liver Disease in Young Womeen, Amer. F. Med., 21, 1956.

Bennett, H. S., Baggenstoss, A. H., and Butt, H. R. (1950): The Testis, Breast and Prostate of Men who Dieơf Cirrhosis of the Liver, Amer. F. clin. Path., 20, 8r 4 .

Birke, G., Diczfalusy, E., and Plantin, L.-O. (I 959): Steroidmetabolismen vid Leversjukdomar, Nord. Med., 6r, 4\&3.

- (1962): The Role of the Liver in the Metabolism of 17-Ketosteroids and Corticosteroids, in 'Aktuelle Problepe der Hepatologie,' Editor G. A. Martini. Stuttgart: Georg Thieme.

Bongiovanni, A. M., and Eisenmenger, W. J. (I95 I): Adrenal Cortical Metabolism in Chronic Liver Disease, $\mathcal{F}$. clizn. Endocr., II, I52.

Brown, H. (1957): Symposium on Hormonal Aspects in Liver Disease, Gastroenterology, 33, 258.

, and ENGLert, E. (196r): Corticosteroid Metabolism in Liver Disease, Arch. intern. Med., ro7, 205.

Brown, J. B. (1955): Urinary Excretion of Oestrogens during Menstrual Cycle, Lancet, i, 320.

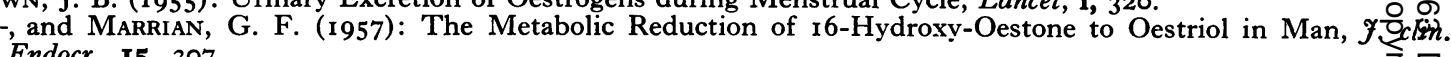
Endocr., I5, 307.

Cameron, C. B. (1957): The Liver and Steroid Hormone Metabolism, Brit. med. Bull., I3, 119. (r957): Urinary Excretion of Oestrone, Oestradiol-17 $\beta$ and Oestriol in Patients with Chronic Liver Darnage f. clin. Endocr., 15, 199.

Cattan, R. P., Vesin, P., and Bodin, H. (1957): Cirrhosis Dysprotéinémiques d'origine inconnue chez la Femnfe, Bull. Soc. méd. Hôp. (Paris), 73, 608.

Chen, P. S., Mrlls, J. H., and BartTer, F. C. (196r): Ultrafiltration Studies of Steroid-Protein Binding, F. Endocr,

Coppage, W. S., Jr., Island, D. P., Cooner, A. E., and Liddle, G. W. (1962): The Metabolism of Aldosterone ${ }^{23}$ n' Normal Subjects and in Patients with Hepatic Cirrhosis, $\mathcal{Y}$. clin. Invest., 4r, 1672. Corda, L. (1925): Sulla c.d. Reviviscenza della Mammella Maschile nella Cirrosi Epatica (Nota Preventiva), Miner ${ }^{\circ} a$
med., 5, 1067.

Davidson, C. S., Sherlock, S., Summerskill, W. H. J., Turner, M. D., and Wolfe, S. J. (i96o): A Comparison⿳亠丷厂f Cirrhosis in Alcoholics in Boston City Hospital and in Non-Alcoholics in Hammersmith Hospital, New Engl, Z. Med., 262, I.

Diczfalusy, E., Franksson, C., and Martinsen, B. (r96r): Oestrogen Conjugation by the Human Intestinal Traêt, Acta endocr. (Kbh.), 38, 59.

—, and Lauritzen, C. (196I): 'Oestrogene beim Menschen'. Berlin, Heidelberg: Springer Verlag.

(1962): Oestrogen Metabolism and Liver Function, in 'Aktuelle Probleme der Hepatologie,' Editor, G. A. Martin̄. Stuttgart: Georg Thieme. Dohan, F. C., Richardson, E. M., Bluemle, L. W., and GyörgY, P. (1952): Hormone Excretion in Liver Diseage,
f. clin. Invest., 3I, 48I.

ENGLeRT, E., Jr., BrowN, H., WALlach, S., and Simon, E. L. (1957): Metabolism of Free and Conjugated r7-Hydroxfcorticosteroids in Subjects with Liver Disease, f. clin. Endocr., 17, 1395.

Eymer, K. P., Schwarz, K., and WeINGES, K. (I96r): Klinische Untersuchungen über den Östrogeneffekt auf das Plasma-Cortisol bei Leberzirrhosen, Gastroenterologia (Basel), 96, 166.

Fletcher, R. F., and Brown, P. S. (1959): Pituitary Function in Malnourished Women, Clin. Sci., r8, 367.

Fraser, R. W., Forbes, A. P., Albright, F., Sulkowitch, H., and Reifenstein, E. C. (I94I): Colorimetric Assay ff $_{\mathrm{f}}$ I7-Ketosteroids in Urine; Survey of Use of this Test in Endocrine Investigation, Diagnosis, and Therapy, $\mathcal{F}$. $c$ b Endocr., 1, 234.

De Gennes, L., Bricaire, H., and Guiot, J. M. (1953): Les Gynécomasties, Presse méd., 6r, 787, J/1 52.

Giuseffi, J., Werk, E. E., LARson, P. U., Schiff, L., and EllioTh, D. W. (1957): Effect of Bilateral Adrenalectorifey in a Patient with Massive Ascites and Postnecrotic Cirrhosis, New Engl. F. Med., 257, 796.

Glass, S. J., Edmonson, H. A., and Soll, S. N. (1944): Excretion of Oestrogen after Injection of Oestradiol and Oestrone into Men with Cirrhosis of Liver, $\mathcal{F}$. clin. Endocr., 4, 54.

Goldgraber, M. B., and KIRSNER, J. C. (I959): Corticotropin (ACTH) and Adrenal Steroids in Liver Disease: Critical Review, Arch. intern. Med., ro4, 469. 
KARK, R. M., Morey, G. R., and PAYnTER, C. R. (195I): Re-Feeding (Nutritional) Gynecomastia in Cirrhosis of the Liver, Amer. F. med. Sci., 222, 154.

Katz, F. H., Lipman, M. M., Frantz, A. G., and Jailer, J. W. (1962): The Physiologic Significance of $6 \beta$-Hydroxycortisol in Human Corticoid Metabolism, . clin. Endocr., 22, 71.

Klatskin, G., Salter, W. T., and Humm, F. D. (1947): Gynecomastia due to Malnutrition: Clinical Studies, Amer. F. med. Sci., 213, 19.

KoczoreK, K. H. R. (r962): Aldosteron-Metabolismus der Leber, in 'Aktuelle Probleme der Hepatologie', Editor, G. A. Martini. Stuttgart: Georg Thieme.

- and WoLFF, H. P. (I959): The Excretion of Endogenous and Exogenous Aldosterone in Dependance on Liverand Kidney-Function in Healthy and Diseased Subjects, Verh. dtsch. Ges. inn. Med., 65, 614.

Layne, D. S., Meyer, C. J., Vaishwanar, P. S., and Pincus, G. (I962): The Secretion and Metabolism of Cortisol and Aldosterone in Normal and in Steroid-treated Women, F. clin. Endocr., 22, 107.

LeE, J., and Bisset, G. W. (1958): The Secretion of Neurohypophyseal Hormones in Man with Special Reference to Liver Disease, Proc. roy. Soc. Med., 51, 36r.

Lloyd, C. W., and Williams, R. H. (1948): Endocrine Changes Associated with Laennec's Cirrhosis of the Liver, Amer. F. med., 4, 315.

LORAINE, J. A. (1958): 'Clinical Application of Hormone Assay', p. I69. London.

LUETSCHER, J. A., and JohNSON, B. B. (1954): Observations on the Sodium-retaining Corticoid (Aldosterone) in the Urine of Children and Adults in Relation to Sodium Balance and Edema, $\mathcal{Y}$. clin. Invest., 33, I44I.

LyngBye, J., and Mogensen, E. F. (I96I): Oestrogen Metabolism in Women with Cirrhosis of the Liver, Acta endocr. $(K b h), 36,350$.

Mackay, J. R. (I96I): The Problem of Persistent Destructive Disease of the Liver, Gastroenterology, 40, 6 I 7.

Marson, F. G. W. (1954): Total Adrenalectomy in Hepatic Cirrhosis with Ascites, Lancet, ii, p. 847.

MARTINI, G. A. (I955): Ủber Gefässveränderungen der Haut bei Leberkranken, Z. klin. Med., 153, 470.

- , and DöLlE, W. (I 960 ): Idiopathische Lebercirrhose bei Frauen in der Menopause, Klin. Wschr., 38, I3.

-, and Staubesand, J. (1953): Zur Morphologie der Gefässpinnen (Vascular Spider) in der Haut Leberkranker, Virchows Arch. path. Anat., 324, 147.

Mills, J. H., Schedl., H. P., CHEN, P. S., and Bartter, F. C. (1960): The Effect of Oestrogen Administration on the Metabolism and Protein Binding of Hydrocortisone, $\mathcal{F}$. clin. Endocr., 20, 515.

MülLER, J. (I958): Über die Oestrogenausscheidung bei der Lebercirrhose des Mannes, Acta endocr. (Kbh.), $28,205$.

Ofstad, J., Stöa, K. F., and Emberland, R. (1962): Adrenal and Urinary Corticosteroids in Terminal Hepatic Failure. Report of a Case, Acta endocr. (Kbh.), 39, 123.

Peterson, R. E. (1960): Adrenocortical Steroid Metabolism and Adrenal Cortical Function in Liver Disease, $\mathcal{~}$. clin. Invest., 39, 320.

- Nokes, G., Chen, P. S., and Black, R. L. (1960): Oestrogens and Adrenocortical Function in Man, f. clin. Endocr., 20, 495.

Pincus, I. J., Rakoff, A. E., Cohn, E. M., and Tumen, I. I. (195I): Hormonal Studies in Patients with Chronic Liver Disease, Gastroenterology, 19, 735 .

Plager, J. E., Tyler, F. H., Hecht, H. H., and Samuels, L. T. (I954): Metabolism and Excretion of Intravenously Administered 4-C ${ }^{14}$-1 7-Hydroxycorticosterone, $\mathcal{F}$. clin. Endocr., 14, 780.

Preedy, J. R. K., and Aitken, E. H. (1956a): The Effect of Oestrogen on Water and Electrolyte Metabolism. II. Hepatic Disease, f. clin. Invest., 35, 430. 35, 423 .

Rupp, J., Cantarow, A., Rakoff, A. E., and Paschis, K. E. (195I): Hormone Excretion in Liver Disease and in Gynecomastia, F. clin. Endocr., II, 688.

Sandberg, A. A., and Slaunwhite, W. R., Jr. (1957): Studies on Phenolic Steroids in Human Subjects. II. The Metabolic Fats and Hepato-Biliary-Enteric Circulation of ${ }^{14} \mathrm{C}$-Oestrone and ${ }^{14} \mathrm{C}$-Oestradiol in Women, $\mathcal{F}$. clin. Invest., 36, 1266.

SchedL, H. P. (1962): Steroid Hormone Metabolism in Liver Disease, in 'Aktuelle Probleme der Hepatologie', G. A. Martini. Stuttgart: Georg Thieme.

Stoa, K. F., Bassoe, H. H., and Emberland, R. (1958): Oestrogen Metabolism in Normal and Pathological Liver Function as Studied by Chromatographic Urine Analysis, Acta endocr. (Kbh.), 28, 357.

StumpF, H. H., and Wilens, S. L. (1953): Inhibitory Effects of Portal Cirrhosis of Liver on Prostatic Enlargement, Arch. intern. Med., 91, 304.

Szego, C. M., and RoBerTS, S. (1953): Steroid Action and Interaction in Uterine Metabolism, Recent Progr. Hormone Res., 8, 419 .

Voegt, H., and WelleR, O. (1959): Die Funktion der männlichen Keimdrüse und der Nebennierenrinde bei akuter Hepatitis und bei Lebercirrhose, Dtsch. med. Wschr., 84, 1093.

Waldenström, J. (1952): Leber, Blutproteine und Nahrungseiweiss, Dtsch. Z. Verdau.-u. Stoffwechselkr. Sonderband, p. III3.

West, C. O., Tyler, F. H., Brown, H., and Samuels, L. T. (195I): Role of Liver and Kidneys in Metabolism of Intravenous Testosterone by Human Subjects, $\mathcal{F}$. clin. Endocr., II, 897.

Willcox, R. G., and Isselbacher, N. J. (I96I): Chronic Liver Disease in Young People, Amer. $\mathcal{F}$. med., $30,185$.

Williams, T. L., Cantarow, A., Paschkis, K. E., and Havens, W. P., Jr. (195I): Urinary 17-Ketosteroids in Chronic Liver Disease, Endocrinology, 48, $65 \mathrm{I}$.

WolfF, H. P., KoczoreK, K. H., and BUCHBorn, E. (1958): Aldosterone and Antidiuretic Hormone (Adiuretin) in Liver Disease, Acta endocr. (Kbh.), 27, 45.

Yates, F. E., Herbst, A. L., Urquhart, J. (1958): Sex Difference in Rate of Ring A Reduction of A4-3 Ketosteroids in Vitro by Rat Liver, Endocrinology 63,887 .

ZoNDEK, B. (1945): Fate of Follicular Hormone in Living Body, Lancet, ii, p. 356.

— and Black, R. (1947): Oestrone Clearance Test in Infectious Hepatitis, F. clin. Endocr., 7, 5 1 9. 